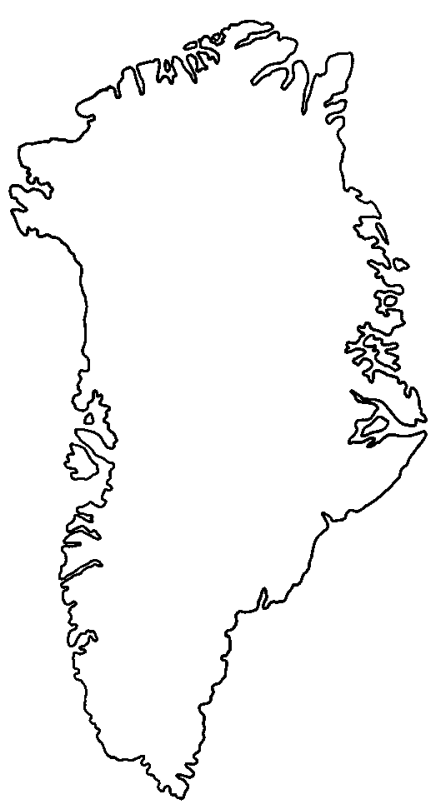

\title{
A Late Permian flora of Pechora affinity in North Greenland
}

\author{
R. H. Wagner, N. J. Soper and \\ A. K. Higgins
}

Late Permian plant impressions comprising six taxa have been obtained from the North Greenland fold belt. Rhipidopsis, a probable ginkgophyte, occurs together with the ferns Prynadaeopteris venusta Radczenko and Pecopteris (Asterotheca?) cf. $P$. (A?) helenaeana Zalessky, the sphenophyte Sphenophyllum cf. $S$. biarnicum Zalessky the cordaitean Cordaites cf. $C$. sylovaensis (Neuburg) Meyen and a possible conifer branch fragment. The assemblage invites comparison with the Pechora flora of the northern Pre-Urals, and also with that of Mongolia and north-eastern China. These may be warm temperate floras on approximately the same palaeolatitude.

R. H.W. \& N. J. S., Department of Geology, The University of Sheffield, Mappin Street, Sheffield S1 3JD, U.K.

A.K.H., Grønlands Geologiske Undersøgelse, Øster Voldgade 10, DK-1350 København K, Danmark.

During the 1979 and 1980 field seasons, several outcrops of post-metamorphic cover rocks were discovered in the North Greenland fold belt in eastern North Greenland (fig. 1). These increase considerably the known extent of the Wandel Sea Basin succession, i.e. the Carboniferous-Palaeogene sediments of eastern North Greenland which post-date the deformation in the North Greenland fold belt and the East Greenland Caledonian fold belt. The new occurrences are in two areas and are both preserved due to post-Palaeozoic tectonic features (fig. 1). One is in north-west Johannes V. Jensen Land and is associated with the Kap Cannon thrust zone. Quartzites and limestones with a marine fauna were found in 1979 on north-west Lockwood $\varnothing$ (Soper et al., 1980). E. Hakansson (personal communication) associated this fauna with that of Lower Permian strata of the Wandel Sea Basin. In 1980 the Lockwood $\varnothing$ sequences proved to rest unconformably on Lower Palaeozoic flysch of the fold belt and to be overlain by shales below the Kap Washington volcanic succession. Similar fossiliferous Permian strata were also found as a thrust slice on the Kap Kane peninsula to the east of Lockwood $\varnothing$.

Several outliers of cover rocks are associated with the Harder Fjord fault zone (fig. 1). This is a major fault zone which traverses the fold belt in an E-W direction and which throws down to the south. In its eastern development, along Frederick E. Hyde Fjord, the fault zone is expressed as a narrow graben, in which Tertiary strata are preserved (Croxton et al., 1980) 


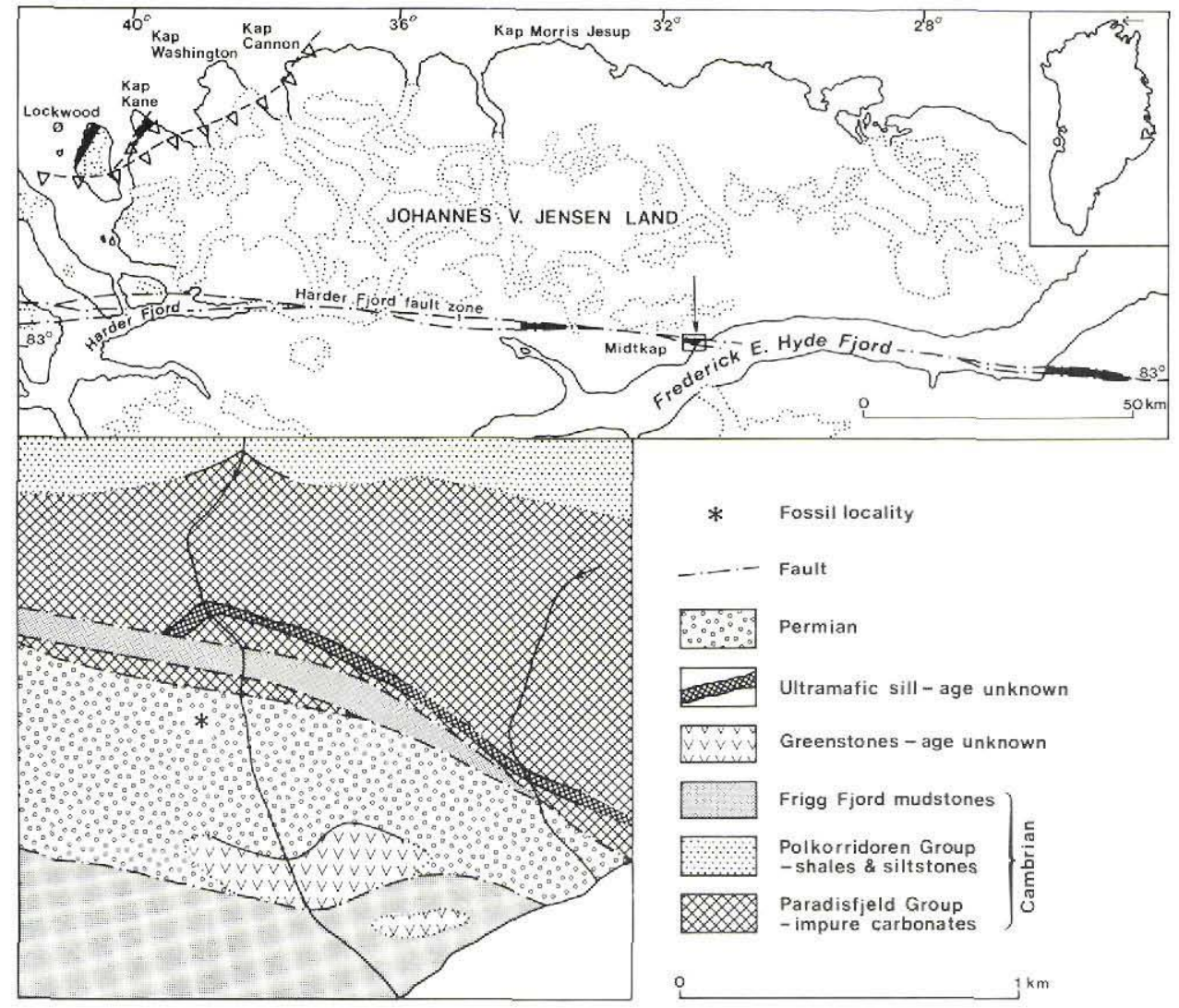

Fig. 1. Location Map. Outcrops of Wandel Sea Basin sediments in central North Greenland are indicated in black. The location of the geological map around the fossil locality is arrowed.

as well as Cretaceous and Permian. This Permian occurrence was found in 1979 and contains the floral remains reported in the present paper. The initial collection proved interesting and further material was collected in 1980 , providing one additional taxon.

The plant bearing strata crop out in a stream section which crosses the northern branch of the Harder Fjord fault zone, north of Frederick E. Hyde Fjord, a few kilometres north-east of Midtkap (fig. 1). Exposure is limited, but the Permian sediments appear to be faulted against calcareous flysch deposits of the Paradisfjeld Group to the north and against greenstones and Frigg Fjord mudstones to the south. A few hundred metres of steeply dipping conglomeratic sandstones are exposed west of the stream. These contain partings of siltstones and shales from which the floral remains were collected. To the east there is an extensive slope of carbonaceous shale debris. The latter proved barren of plant remains, and also of pollen and spores. 


\section{Description of floral remains}

The plant fossils occur in dark grey, silty mudstones which are blocky in places due to the presence of sideritic ironstone. Fissility is variable and may be related in part to silty streaks which show a hint of cross-lamination. This indication of current activity agrees with the presence of abundant small carbonaceous debris at certain horizons. On the other hand, the identifiable plant fossils consist of large frond fragments of two ferns, a pecopterid and a sphenopterid, together with fairly cohesive large palmate leaves of the probable ginkgophyte Rhipidopsis, and sizeable fragments of cordaitean leaves. Two other taxa are present with only single fragments. The identifiable plant remains occur on certain bedding planes which represent the deposition of finer grained mudrock. The large size of a number of specimens (one fragment measures about $25 \mathrm{~cm}$ and extends to the edge of a broken slab) precludes transport over a long distance.

Rhipidopsis sp. (fig. 2) is represented by petiolate, palmate leaves subdivided into long, cuneate segments, twice cleft at the apex. The segments differ in length depending on their position within the leaf, and are 5 to $10 \mathrm{~cm}$ long and 1 to $2 \mathrm{~cm}$ wide. The veins are subparallel and dichotomising, and the vein density is about 28 per centimetre across the width of the segment. These leaves are most similar to that figured as Rhipidopsis aff. $R$. palmata Zalessky by Durante (1976, pl. LII, fig. 2) from Mongolia. They may also be compared with Rhipidopsis baieroides Kawasaki \& Kon'no as figured from north-eastern China (Kon'no 1968, pl. 23-24). However, it is noted that the type $R$. baieroides, from the Kobosan Beds of Korea, shows a more highly dissected leaf with a very marked variation in the size of leaf segments. Both the Mongolian and north-eastern Chinese specimens came from Upper Permian strata.

Pecopteris (Asterotheca?) cf. P. (A?) helenaeana Zalessky (fig. 3) occurs with many large sterile frond fragments as well as a few small remains showing poorly preserved sori. The species is characterised by closely adpressed pinnules, confluent at the base in the more distal parts of pinnae but slightly constricted at the base in the much more elongate pinnules in the lower parts of pinnae. Fragments of pinnae up to the penultimate order have been found. Pinnule insertion is characteristically subperpendicular and the size is very variable, ranging from some 4 to $15 \mathrm{~mm}$ in length in non-lobing pinnules. Their width is more constant and ranges from 2 to $3 \mathrm{~mm}$. Gradually lobing, even more elongate pinnules seem to effect a gradual transition to pinnae of the last order. The venation consists of a well marked midvein and strongly developed, oblique laterals. These are generally forked only once but are more rarely three-pronged. Vein density is about 12 per $\mathrm{cm}$ on the pinnule margin. The smallest individualised pinnules show simple veins (fig. $3 \mathrm{D}$ ). Poorly preserved sori (Asterotheca?) fill the spaces between the midvein and the pinnule margin in a few specimens.

The comparison with Pecopteris helenaeana Zalessky, suggested by S. V. Meyen (personal communication), is supported by the fact that this species is also characterised by large pinnules with a wide venation consisting of a strong midvein and mainly once forked laterals oblique to the pinnule margin. Zalessky \& Tchirkova $(1937$, p. 29) describe this species as possessing a strongly marked nervation which is also an obvious feature of the present specimens. P. helenaeana also shows gradual lobing with a nervuary development of the Lobatopteris kind, a development which has also been observed in the material from North Greenland. The shape of the pinnules also appears to be similar, as is the insertion and the tendency for a confluent base to be present in the smaller pinnules. However, the pinnules of 

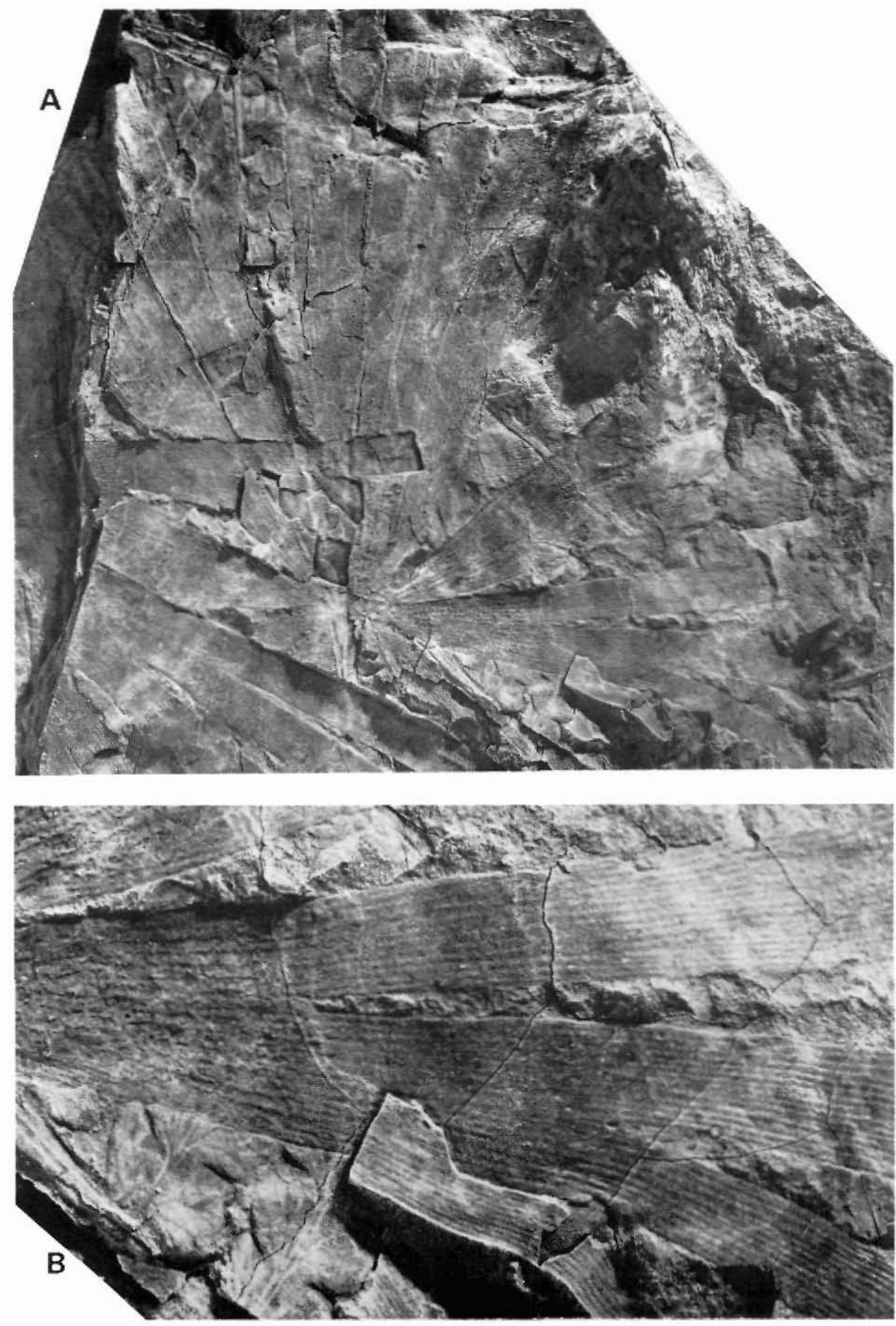

Fig. 2A. Rhipidopsis sp., $\times$ 1. MGUH 15.965 from GGU 255770.

2B. Detail of the same specimen showing venation of a leaf segment cleft twice at the distal end $\times 3$. 

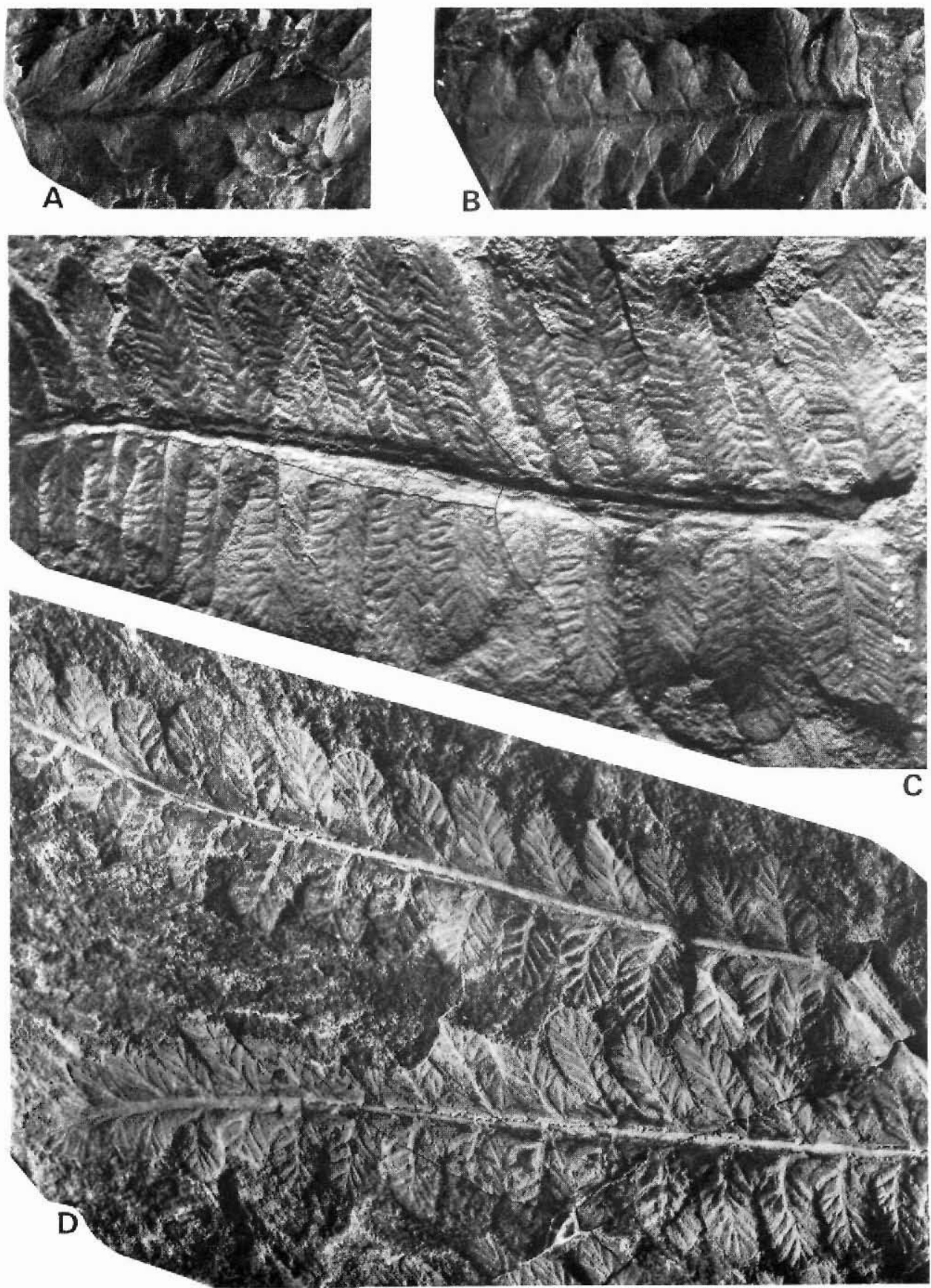

Fig. 3A, B. Prynadaeopteris venusta Radczenko, × 3. MGUH 15.966 from GGU 255770.

3C, D. Pecopteris cf. P. helenaeana Zalessky, pinna fragments showing some of the variation in pinnule size and venation, $\times 3$. MGUH 15.967 and 15.968 from GGU 255770. 


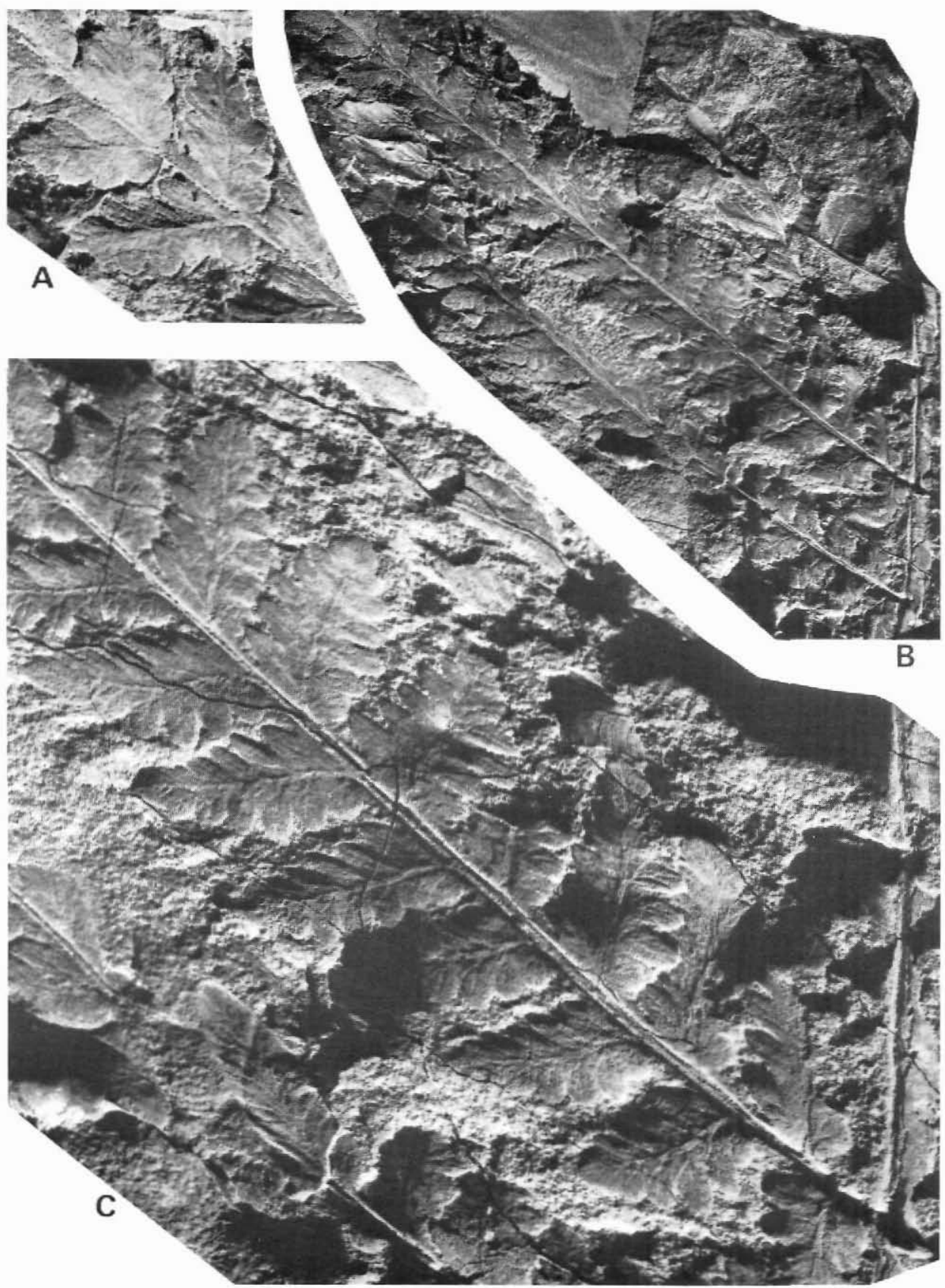

Fig. 4A-C. Prynadaeopteris venusta Radczenko. Single specimen $\times 1$ (B) and $\times 3$ (A, C) showing pinnule shape in a lobing part of the frond. MGUH 15.969 from GGU 255770. 
$P$. helenaeana have been described as up to $7 \mathrm{~mm}$ wide, whereas the specimens in hand show generally narrower pinnules. $P$. helenaeana Zalessky occurs in the Upper Permian of the Pechora and East European areas (cf. Meyen in Vakhremeev et al., 1978). A much more remote resemblance exists with regard to Pecopteris robustissima Wagner of the upper Stephanian in western Europe and the Caucasus (Shchegolev, 1979).

Prynadaeopteris venusta Radczenko (figs 3 and 4) has been found in smaller pinna fragments (remains of up to penultimate order) with quite variable, thin-limbed pinnules which tend to a subtriangular shape and which show very gradual lobing. The venation consists of a thin, flexuous midvein and widely spaced, simple to once forked laterals. Some specimens exhibit marginal sori placed at the end of lateral veins. Although the preservation is too poor to show the annulus, the obvious comparison is with Oligocarpia. The foliage is also quite similar to that of Oligocarpia leptophylla (Bunbury) Grauvogel-Stamm \& Doubinger from the upper Stephanian and Autunian of Europe. However, a more direct comparison can be made with Prynadaeopteris venusta Radczenko, a species close to Prynadaeopteris anthriscifolia (Goeppert) Radczenko. The genus Prynadaeopteris shows sori similar to those of Oligocarpia, but apparently without an annulus (Fefilova, 1973). P. anthriscifolia has often been compared and even placed in synonymy with 'Pecopteris' leptophylla Bunbury, but the comparison has been with Dicksonites leptophylla Doubinger (= Pecopteris leptophylla Zeiller, non Bunbury). It seems likely that the genus Prynadaeopteris and its affinities need to be examined more closely.

Sphenophyllum cf. S. biarnicum Zalessky occurs with a single fragmentary whorl showing five leaves of unequal size (probably originally six leaves in the whorl), up to a maximum of $15 \mathrm{~mm}$ long at 6-7 mm width, with the distal border broadly rounded and grading into lateral borders. Veins are rather widely spaced and end on the distal border as well as high on the lateral borders. This specimen is similar to Zalessky's (1937, p. 44-46) species from the Pechora Basin, particularly in the size and shape of the leaves. The relatively wide veining also coincides, but there seems to be a higher proportion of veins abutting onto the lateral border in the specimen figured from the northern USSR. It is also possible to compare with Sphenophyllum speciosum Royle and Sphenophyllum sinocoreanum Yabe. All these are Late Permian species.

Cordaites cf. C. sylovaensis (Neuburg) Meyen refers to cordaitean leaf fragments with closely spaced parallel veins with very occasional vein bifurcations. S. V. Meyen (personal communication, 1980) has suggested the comparison.

A branch fragment with attached, simple leaves shows a resemblance to Bardella, a presumed conifer described by Zalessky (1937). The specimen is poorly preserved and the identification is highly tentative.

\section{Discussion}

The preliminary identifications made thus far indicate the presence of six taxa, viz. Rhipidopsis sp., Pecopteris (Asterotheca ?) cf. P.(A?) helenaeana Zalessky, Prynadaeopteris venusta Radczenko, Sphenophyllum cf. S. biarnicum Zalessky, Cordaites cf. C. sylovaensis (Neuburg) Meyen and ?Bardella sp. This assemblage is most comparable to that of the Upper Permian (Kazanian-Tatarian) of the Pre-Urals Pechora Basin. The Pechora Province (Meyen in Vakhrameev et al., 1978, p. 96) forms a special palaeofloristic unit on the western margin of the Angara Realm, showing transitions to the Taimyr-Kuznetsk area to the east 
and the East European area to the west. It is characterised by the presence of Angaran genera together with a more varied representation of ferns, as well as Rhipidopsis, etc. Among the North Greenland floral remains there are several that also invite comparison with the Kuznetsk and Tunguska basins, whilst the Rhipidopsis remains are most similar to those recorded from Mongolia and north-east China. It is clear that the assemblage from North Greenland represents a palaeofloristic zone marginal to the general Angara Realm and bordering more equatorial floras of the Euramerican and Cathaysian areas. The difference between the latter two 'provinces' is apparently related to more arid and more humid climatic regions and is not a matter of palaeolatitude. The palaeofloristic zone to which the North Greenland flora belongs, is most likely to be interpreted as a latitudinal belt on the northern hemisphere of the Permian plate configuration. Its floras may be regarded as warm temperate, and a humid climate may be envisaged.

The palaeofloristic interpretation of the North Greenland plant remains, i.e. the identification with the Pechora Province, apparently agrees well with the recent records of Late Permian and Triassic microfloras from East Greenland reported by Balme (1979), who showed assemblages comparable to those of East Europe. This may be partly a matter of palaeolatitude and partly a reflection of the more arid climate of the North-West European Zechstein and early Trias.

\section{Conclusions}

The presence of floral remains belonging to a palaeofloristic zone marginal to the Angara Realm is not wholly unexpected in North Greenland. A prediction to that effect is implicit in the map of Permian floral provinces published by Wagner (1962), and a similar prediction is contained in the map published by Meyen (1973). The significance of floras for the reconstruction of palaeolatitudinal belts has long been recognised but fitting the floristic data to palaeomagnetic reconstructions of the late Palaeozoic plate configurations is still difficult. On the latest reconstruction of the northern hemisphere for $240 \mathrm{~m} . \mathrm{y}$. by Smith et al. (1981) the North Greenland and northern Ural occurrences do occupy a common palaeolatitude in about $45^{\circ} \mathrm{N}$. However, when traced eastwards to the Soviet Far East and north-east China, the marginal Angaran belt appears to cross the lines of palaeolatitude at a high angle. The location of this region is poorly constrained by the palaeomagnetic data.

Acknowledgements. Comments and suggestions provided by S. V. Meyen of the Geological Institute of the Academy of Sciences of the USSR are most gratefully acknowledged. It is hoped to describe the floral remains in more detail in collaboration with Dr. Meyen, and in direct comparison with material from the Pechora Basin. B. Pigott (Sheffield) is thanked for the photographs illustrating floral remains. MGUH and GGU denote collections of the Geological Museum, Copenhagen, and the Geological Survey of Greenland, respectively.

\section{References}

Balme, B. E. 1979: Palynology of Permian-Triassic boundary beds at Kap Stosch, East Greenland. Meddr Grønland 200(6), $37 \mathrm{pp}$.

Croxton, C. A., Dawes, P. R., Soper, N. J. \& Thomsen, E. 1980: An occurrence of Tertiary shales from the Harder Fjord Fault, North Greenland fold belt, Peary Land. Rapp. Grønlands geol. Unders. 101, 61-64. 
Durante, M. V. 1976: The Carboniferous and Permian stratigraphy of Mongolia on the basis of palaeobotanical data (in Russian). Trudy Sovest. Sovet-Mongol. Nauko-issled. geol. Eksped. 19, 279 pp.

Fefilova, L. A. 1973: Fernlike plants from the Upper Permian of the North Pre-Ural downwarp (in Russian). Akad. Nauk Komi Filial Inst. Geol., 192 pp. Leningrad: Nauka.

Kon'no, E. 1968: The Upper Permian flora from the eastern border of Northeast China. Sci. Rep. Tohoku Univ. Sendai 2 Ser. (Geol.) 39(3), 159-211.

Meyen, S. V. 1973: Über die Hypothese der Kontinentaldrift unter dem Aspekt der Paläobotanik des Karbons und Perms. Z. geol. Wiss., Berlin 1(4), 417-431.

Shchegolev, A. K. 1979: Upper Carboniferous of North Caucasus in Zelenchuk-Teberda interfluve (Flora, vegetation, stratigraphy, palaeogeography). (in Russian). Akad. Nauk Ukrainskoi SSR, Geol. Instit., Kiev, 196 pp.

Smith, A. G., Horsley, A. M. \& Briden, J. C. 1981: Phanerozoic Palaeocontinental World Maps. 98 pp. Cambridge U.P.

Soper, N. J., Higgins, A. K. \& Friderichsen, J. D. 1980: The North Greenland fold belt in eastern Johannes V. Jensen Land. Rapp. Grønlands geol. Unders. 99, 89-98.

Vakhrameev, V. A., Dobruskina, I. A., Meyen, S. V. \& Zaklinskaja, E. D. 1978: Paläozoische und mesozoische Floren Eurasiens und die Phytogeographie dieser Zeit. VEB Gustav Fischer Verlag Jena, 300 pp.

Wagner, R. H. 1962: On a mixed Cathaysia and Gondwana flora from SE Anatolia (Turkey). C. R. IV Congr. Strat. Géol. Carb. Heerlen 1958, II, 745-752.

Zalessky, M. D. 1934: Observations sur les végétaux permiens du bassin de la Petchora. I. Bull. Acad. Sci. URSS. Cl. Math. Nat. 1934 (2-3), 241-289.

Zalessky, M. D. 1937: Sur la distinction de l'étage Bardien dans le Permien de l'Oural et sur sa flore fossile. Voprosy Paleont. II-III, 37-101.

Zalessky, M. D. \& Tchirkova, H. Th. 1937: Flore permienne de l'Oural petchorien et de la chaîne Païkhoï. Acad. Sc. USSR, La base du Nord, 1-56. 